\title{
Drying kinetics and thermodynamic properties of bitter melon (Momordica charantia L.) leaves
}

\author{
Daniel P. da Silva ${ }^{1}$, Samuel G. F. dos Santos ${ }^{2}$, Isneider L. Silva ${ }^{3}$, Hellismar W. da Silva ${ }^{4} \&$ \\ Renato S. Rodovalho ${ }^{1}$
}

${ }^{1}$ Instituto Federal de Educação, Ciência e Tecnologia Goiano/ Campus Ceres. Ceres, GO, Brasil. E-mail: danielsilva.agron@gmail.com (Corresponding
author) - ORCID: 0000-0002-7217-2886; renato.rodovalho@ifgoiano.edu.br - ORCID: 0000-0002-0558-4098
${ }^{2}$ Universidade Federal de Viçosa. Viçosa, MG, Brasil. E-mail: samuel-2100@hotmail.com - ORCID: 0000-0003-1618-6877
${ }^{3}$ Universidade Estadual de Goiás. Anápolis, GO, Brasil. E-mail: isneider.luiz@gmail.com - ORCID: 0000-0002-0609-3274
${ }^{4}$ Universidade Federal de Lavras/Departamento de Agricultura. Lavras, MG, Brasil. E-mail: waksonhellismar@gmail.com - ORCID: 0000-0002-1353-2247

\begin{abstract}
Bitter melon (Momordica charantia L.) is a versatile plant that can be consumed as a food and has therapeutic applications. Studying its drying process is important to maintain their leaf quality during storage. The objective of this study was to evaluate the drying kinetics of bitter melon leaves and determine their thermodynamic properties. The leaves were placed in polyethylene trays and subjected to drying in an oven at temperatures of $20,30,40$, and $50{ }^{\circ} \mathrm{C}$ until reaching hygroscopic equilibrium. The experimental data were fitted to several non-linear regression models to characterize the drying process. The Arrhenius model was used to obtain the coefficients of diffusion and the activation energy, which were used to calculate the enthalpy, entropy, and the Gibbs free energy. Midilli and Page were the best models to represent the drying kinetics of bitter melon leaves at temperatures of $20,30,40$, and $50^{\circ} \mathrm{C}$. Increases in the drying air temperature increased the Gibbs free energy and water diffusivity in the interior of the leaves. Enthalpy and entropy decreased as the temperature was increased.
\end{abstract}

Key words: diffusivity, Midilli, Page, moisture, medicinal plant

\section{Cinética de secagem e propriedades termodinâmicas das folhas do melão-de-são-caetano (Momordica charantia L.)}

RESUMO: O melão-de-são-caetano (Momordica charantia L.) é uma planta versátil que pode ser consumida como alimento e possui aplicações terapêuticas. Desta forma, o estudo sobre o processo de secagem é de suma importância para manter a qualidade de suas folhas durante o armazenamento. Objetivou-se, com esta pesquisa, avaliar a cinética de secagem das folhas de melão-de-são-caetano, bem como determinar suas propriedades termodinâmicas. As folhas foram dispostas em bandejas de polietileno e submetidas a secagem em estufa nas temperaturas de $20,30,40$ e $50{ }^{\circ} \mathrm{C}$ até atingir o equilíbrio higroscópico. Diversos modelos de regressão não linear foram ajustados aos dados experimentais para caracterizar o processo de secagem. A partir do modelo de Arrhenius foram obtidos os coeficientes da difusão e a energia de ativação para o cálculo da entalpia, entropia e energia livre de Gibbs. Os modelos de Midilli e Page foram os melhores para representação da cinética de secagem das folhas de melão-de-são-caetano nas temperaturas de 20, 30, 40 e $50{ }^{\circ} \mathrm{C}$. $\mathrm{O}$ aumento da temperatura do ar de secagem aumenta a energia livre de Gibbs e a difusividade de água no interior das folhas. A entalpia e a entropia diminuem com o aumento da temperatura.

Palavras-chave: difusividade, Midilli, Page, teor de água, planta medicinal 


\section{INTRODUCTION}

Bitter melon (Momordica charantia L.) is a common vine found in the coastal region and interior of Brazil that is known by its use in cooking and medicine (Joly, 1998). It is a medicinal plant that can be easily obtained; studies report its use in several countries, such as Brazil, China, Colombia, Cuba, Ghana, Haiti, India, Mexico, Malaysia, Nova Zealandia, Nicaragua, Panama, and Peru (Assis et al., 2015).

Drying is one of the main processes that assist in the maintenance of agricultural products, which is needed for a better use and maintenance of the active principle of bitter melon leaves (Rodovalho et al., 2015).

The activation energy represents the difficult level of water molecules to overcome the energy barrier in their migration in the interior of a product (Corrêa et al., 2007). It enables the determination of thermodynamics properties that provide information about the mechanism of control of water vapor sorption (Viganó et al., 2012).

Information on thermodynamic properties in the drying process of leaves is important for designing the drying equipment, calculating the energy required for the process, studying properties of the adsorbed water, evaluating food microstructures, and studying the physical phenomena that occur on the surface of agricultural products (Corrêa et al., 2010).

Therefore, the objective of this study was to evaluate the drying kinetics of bitter melon leaves at temperatures of 20,30, 40 , and $50^{\circ} \mathrm{C}$ and determine their thermodynamic properties.

\section{MATERIAL AND Methods}

The experiment was conducted at the Laboratory of Plant Physiology of the Federal Institute Goiano (FIG), in Ceres, GO, Brazil ( $15^{\circ} 18^{\prime} 49^{\prime \prime} \mathrm{S}, 49^{\circ} 36^{\prime} 12^{\prime \prime} \mathrm{W}$, and altitude of $630 \mathrm{~m}$ ), in August 2015. Bitter melon leaves were randomly collected in regions near the FIG campus, at the first hours of the morning without dew on the leaf surfaces.

Homogeneous leaves without damages caused by pathogens or insects were selected to avoid their effects on the results.

The initial equilibrium water content of the samples was measured after the selection of the product and at the end of the drying by the gravimetric method in a forced-air circulation oven at $103 \pm 1{ }^{\circ} \mathrm{C}$ for $24 \mathrm{~h}$, with four replications (ASABE, 2010).

The leaves were dried at temperatures of 20,30, 40 and 50 ${ }^{\circ} \mathrm{C}$; the temperatures were controlled by a biochemical oxygen demand (BOD) chamber.

The samples were cut using a square template with an area of $17.2 \mathrm{~mm}^{2}$, and a thin layer was deposited in polyethylene trays. Approximately $2 \mathrm{~g}$ of sample per replication were placed in the trays at the beginning of the drying process, using four replications for each temperature, and were weighed periodically in a digital analytical balance with precision of $0.1 \mathrm{mg}$ until the samples reach equilibrium water content with the drying air.

The interval between weighing started with $20 \mathrm{~min}$ and increased up to $10 \mathrm{~h}$ to monitor the hygroscopic equilibrium.
The water content ratio was calculated during the drying processes, using Eq. 1.

$$
\mathrm{RX}=\frac{(\mathrm{X}-\mathrm{Xe})}{(\mathrm{X}-\mathrm{Xi})}
$$

where:

RX - water content ratio, dimensionless;

$\mathrm{X}$ - leaf water content, $\mathrm{kg}$ of water per $\mathrm{kg}$ of leaf dry weight;

$\mathrm{Xe} \quad$ - leaf equilibrium water content, $\mathrm{kg}$ of water per $\mathrm{kg}$ of leaf dry weight; and,

$\mathrm{Xi}$ - leaf initial water content, $\mathrm{kg}$ of water per $\mathrm{kg}$ of leaf dry weight.

The bitter melon leaf water content data were fitted to non-linear regression models (Table 1). Experimental data of drying blackberry (Morus nigra) leaves were also fitted to these models by Martins et al. (2018).

Table 1. Non-linear regression models used to estimate the drying of bitter melon leaves

\begin{tabular}{|c|c|c|}
\hline Model & Model equation & \\
\hline Diffusion approach & $R X=a \exp (-k t)+(1-a) \exp (-k b t)$ & (2) \\
\hline Two-term & $R X=a \exp (-k t)+b \exp (-c t)$ & (3) \\
\hline Two-term exponential & $R X=a \exp (-k t)+(1-a) \exp (-k a t)$ & (4) \\
\hline Henderson and Pabis & $R X=a \exp (-k t)$ & (5) \\
\hline Logarithm & $R X=a \exp (-k t)+b$ & (6) \\
\hline Midilli & $R X=a \exp \left(-k t^{n}\right)+b t$ & (7) \\
\hline Newton & $R X=\exp (-k t)$ & (8) \\
\hline Page & $R X=\exp \left(-k t^{n}\right)$ & (9) \\
\hline
\end{tabular}
drying; a, b, c, and n - Parameters of the models

The best models to represent the bitter melon leaf drying kinetics were selected, considering the significance of the coefficients of regression by the $t$ test at $p \leq 0.05$, and the magnitude of coefficient of determination $\left(\mathrm{R}^{2}\right)$, relative mean error $(\mathrm{P})$, and standard deviation of the estimate (SD).

The mathematical model for drying kinetics was selected considering the highest $\mathrm{R}^{2}$, $\mathrm{p}$-value below $10 \%$, and the lowest SD.

The standard deviation of the estimate (SD) and relative mean error $(\mathrm{P})$ were calculated using Eqs. 10 and 11.

$$
\begin{aligned}
& \mathrm{SD}=\sqrt{\sum_{\mathrm{i}=1}^{\mathrm{N}} \frac{(\mathrm{Y}-\hat{\mathrm{Y}})^{2}}{\mathrm{DF}}} \\
& \mathrm{P}=\frac{100}{\mathrm{~N}} \sum_{\mathrm{i}=1}^{\mathrm{N}}\left(\frac{|\mathrm{Y}-\hat{\mathrm{Y}}|}{\mathrm{Y}}\right)
\end{aligned}
$$

where:

$$
\begin{array}{ll}
\mathrm{N} & \text { - number of experimental observations; } \\
\mathrm{Y} & \text { - experimental water content ratio; } \\
\hat{\mathrm{Y}} & \text { - predicted moisture ratio; and, } \\
\mathrm{DF} & \text { - degrees of freedom of the residue. }
\end{array}
$$

The dimensions and mean thickness of the sampled leaves were used to obtain the coefficient of effective diffusion by 
adjusting the mathematical model of the net diffusion to eight terms, as described in Eq. 12, considering the product geometry as a plain body, disregarding leaf volumetric contractions (Brooker et al., 1992).

$$
\mathrm{RX}=\sum_{\mathrm{n}=1}^{\infty} \frac{4}{\lambda \mathrm{n}^{2}} \exp \left(-\frac{\lambda \mathrm{n}^{2}}{\mathrm{~L}^{2}} \mathrm{D}_{\mathrm{ef}} \mathrm{T}\right)
$$

where:

RX - water content ratio, dimensionless;

$\mathrm{D}_{\text {ef }}$ - coefficient of effective diffusion;

$\mathrm{T}$ - time, s;

n - number of terms;

L - product thickness, $\mathrm{m}$; and,

$\lambda \mathrm{n}$ - square roots of the Bessel equation of first type, with order 0 .

The correlation between increases in the coefficient of effective diffusion $\left(D_{\text {ef }}\right)$ and increases in the drying air temperature was evaluated by Eq. 13, which represents the Arrhenius model.

$$
\mathrm{D}_{\mathrm{ef}}=\mathrm{D}_{0} \exp \left(\frac{\mathrm{E}_{\mathrm{a}}}{\mathrm{RT}_{\mathrm{a}}}\right)
$$

where:

$$
\begin{array}{ll}
\mathrm{D}_{0} & \text { - pre-exponential factor; } \\
\mathrm{T}_{\mathrm{a}} & \text { - absolute temperature, } \mathrm{K} ; \\
\mathrm{R} & \text { - gas universal constant, } 8.314 \mathrm{~kJ} \mathrm{kmol}^{-1} \mathrm{~K}^{-1} \text {; and, } \\
\mathrm{E}_{\mathrm{a}} & \text { - activation energy, } \mathrm{kJ} \mathrm{mol}{ }^{-1} \text {. }
\end{array}
$$

The coefficients of the Arrhenius model were obtained using the logarithm expressed by Eq. 14 .

$$
\ln \left(\mathrm{D}_{\mathrm{ef}}\right)=\ln \left(\mathrm{D}_{0}\right)-\frac{\mathrm{E}_{\mathrm{a}}}{\mathrm{R}} \frac{1}{\mathrm{~T}_{\mathrm{a}}}
$$

The thermodynamic properties of the dried bitter melon leaves were determined by the method described by Jideanie \& Mpotokwana (2009) and Corrêa et al. (2010). Enthalpy $(\Delta \mathrm{h})$ was calculated using Eq. 15; entropy $(\Delta s)$ was calculated using Eq. 16; and the Gibbs free energy $(\Delta \mathrm{G})$ was calculated using Eq. 17.

$$
\begin{gathered}
\Delta \mathrm{h}=\mathrm{E}_{\mathrm{a}}-\mathrm{RT}_{\mathrm{a}} \\
\Delta \mathrm{s}=\mathrm{R}\left(\ln \mathrm{D}_{0}-\ln \frac{\mathrm{k}_{\mathrm{b}}}{\mathrm{h}_{\mathrm{p}}}-\ln \mathrm{T}_{\mathrm{a}}\right) \\
\Delta \mathrm{G}=\Delta \mathrm{h}-\Delta \mathrm{T}_{\mathrm{a}} \Delta \mathrm{s}
\end{gathered}
$$

where:

$$
\begin{array}{ll}
\Delta \mathrm{h} & \text { - specific enthalpy, } \mathrm{J} \mathrm{mol}^{-1} ; \\
\Delta \mathrm{s} & - \text { specific entropy, } \mathrm{J} \mathrm{mol}^{-1} \mathrm{~K}^{-1} ; \\
\Delta \mathrm{G} & - \text { Gibbs free energy, } \mathrm{J} \mathrm{mol}^{-1} ; \\
\mathrm{kb} & - \text { Boltzmann's constant, } 1.38 \times 10^{-23} \mathrm{~J} \mathrm{~K}^{-1} \text {; and, }
\end{array}
$$

$$
\mathrm{hp}=\text { Planck's constant, } 6.626 \times 10^{-34} \mathrm{~J} \mathrm{~s}^{-1} \text {. }
$$

\section{Results AND Discussion}

The experimental data fitted to the models (Table 2), presenting $\mathrm{R}^{2}$ above $97 \%$, except the two-term exponential model at temperature of $30^{\circ} \mathrm{C}(61.71 \%)$ and diffusion approach model for temperature of $40^{\circ} \mathrm{C}(92.97 \%)$.

The Midilli model showed the highest $\mathrm{R}^{2}$; high $\mathrm{R}^{2}$ indicate a better fit of the experimental data to the model (Karizaki, 2016). However, according to Mohapatra \& Rao (2005), the use of $\mathrm{R}^{2}$ as the only evaluation criterion to select drying models is not adequate, thus requiring a joint analysis of fitting indexes.

The Midilli model presented the lowest relative mean error (P) (Table 2). Mohapatra \& Rao (2005) recommend the use of joint analysis of all temperatures involved with the drying process with relative mean error lower than $10 \%$.

The Midilli model presented the lowest standard deviation (SD); according to Draper \& Smith (1998), the capacity of a model to describe a physical process with reliability is inverse to the $\mathrm{SD}$, therefore, the lower the $\mathrm{SD}$, the better the fit to the model.

Considering the $\mathrm{R}^{2}, \mathrm{P}$, and $\mathrm{SD}$, the Midilli model was chosen to represent the drying kinetics of bitter melon leaves.

Studies on drying of other medicinal plant species have used the Midilli model due to its better fit of the experimental data. This was recommended by Corrêa Filho et al. (2018) who

\begin{tabular}{|c|c|c|c|c|c|c|}
\hline \multirow{2}{*}{ lodel } & $\mathrm{R}^{2}$ & $\mathbf{P}$ & \multirow{2}{*}{$\begin{array}{c}\text { SD } \\
\text { (decimal) }\end{array}$} & $\mathrm{R}^{2}$ & P & \multirow{2}{*}{$\begin{array}{c}\text { SD } \\
\text { (decimal) }\end{array}$} \\
\hline & \multicolumn{2}{|r|}{$(\%)$} & & & \\
\hline & \multicolumn{3}{|c|}{$20^{\circ} \mathrm{C}$} & \multicolumn{3}{|c|}{$30^{\circ} \mathrm{C}$} \\
\hline Diffusion ap & 99.92 & 2.7137 & 0.00018 & 99.87 & 1.8495 & 0.0003 \\
\hline Two-term & 99.93 & 2.6968 & 0.00018 & 99.87 & 2.0194 & 0.0003 \\
\hline Two-term exponential & | 99.92 & 2.6791 & 0.00020 & 61.71 & 63.5411 & 0.1088 \\
\hline Henderson and Pabis & 99.87 & 2.4640 & 0.00030 & 99.74 & 4.6480 & 0.0007 \\
\hline Logarithm & 99.94 & 2.7633 & 0.00030 & 99.87 & 2.1964 & 0.0003 \\
\hline Midilli & 99.95 & 1.5565 & 0.00011 & 99.18 & 2.1961 & 0.0003 \\
\hline Newton & 99.82 & 2.2805 & 0.00045 & 99.74 & 4.8128 & 0.0007 \\
\hline \multirow[t]{2}{*}{ Page } & 99.89 & 3.2520 & & 98.85 & 2.4740 & 0.0004 \\
\hline & \multicolumn{3}{|c|}{$40^{\circ} \mathrm{C}$} & \multicolumn{3}{|c|}{$50^{\circ} \mathrm{C}$} \\
\hline Diffu & 92.9 & 49.2894 & & 99.54 & 11.6365 & 0.0012 \\
\hline Two - & 99.97 & 3.5560 & 0.00010 & 99.87 & 5.3703 & 0.0003 \\
\hline Two- & | 99.89 & 6.6119 & 0.00040 & 99.83 & 5.1374 & 0.0004 \\
\hline Henders & 99. & 6.6104 & 0.00030 & 99.66 & 9.5608 & 0.0009 \\
\hline Logarithm & 97.56 & 1.0141 & 0.0 & 99.82 & 7.4054 & 0.0004 \\
\hline Midilli & 99.99 & 1.2094 & 0.00 & 99.70 & 5.1614 & 0.0008 \\
\hline Newton & 99.87 & 5.8548 & & 99.53 & 11.6363 & 0.0012 \\
\hline Page & 99.86 & 6.0689 & 0005 & 99.79 & 4.5235 & 0.0006 \\
\hline
\end{tabular}
evaluated the drying of parsley plants at temperatures of 40 , 50 , and $60^{\circ} \mathrm{C}$, and by Goneli et al. (2014a) who evaluated the drying of Schinus terebinthifolius leaves at the temperatures of $40,50,60$, and $70{ }^{\circ} \mathrm{C}$.

The bitter melon leaf drying period decreases as the drying air temperature was increased (Figure 1); this was because of increases in the pressure gradient between the interior of the leaf and the surrounding air. The water content of bitter melon leaves subjected to air drying at temperatures of 20,30, 40, and $50{ }^{\circ} \mathrm{C}$ was low, approximately 3.20 to 0.35 dry basis.

Table 2. Coefficient of determination $\left(\mathrm{R}^{2}\right)$, relative mean error (P), and standard deviation of the estimate (SD) as criteria to fit experimental data of bitter melon leaves to drying models, obtained at temperatures of $20,30,40$, and $50{ }^{\circ} \mathrm{C}$ 


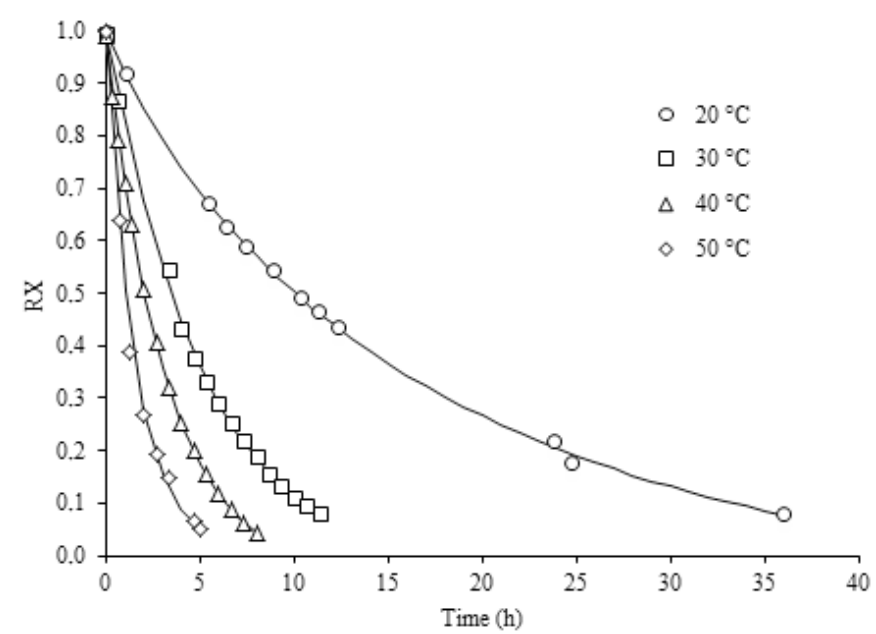

Figure 1. Experimental and estimated values for water content ratio (RX) by estimates of parameters of the Midilli equation as a function of drying time of bitter melon leaves, at the temperatures of $20,30,40$, and $50{ }^{\circ} \mathrm{C}$

The drying time decreased as the temperatures was increased. This can be explained by increases in the pressure gradient between the drying air and the interior of the leaves, and indicates a greater decrease of water content in less time.

This was also found for the drying of leaves of Cordia verbenacea, Ziziphus joazeiro, and Mentha piperita (Goneli et al., 2014b; Sousa et al., 2015; Gasparin et al., 2017).

The Midilli model is also used for the fit of drying kinetics, as recommended by Martins et al. (2018), who evaluated the drying of blackberry leaves at temperatures of 40,50,60, and $70{ }^{\circ} \mathrm{C}$.

The $\mathrm{k}$ coefficient of the Midilli model increased from 0.077462 to 0.690506 as the temperature was increased (Table 3). This coefficient can be used to characterize the effect of temperature and is related to the effective diffusivity in the drying process in a decreasing period, because the liquid diffusion controls the drying process (Babalis \& Belessiotis, 2004).

The $\mathrm{D}_{\text {ef }}$ values increased in $4.38,13.9,24.1$, and $38.1 \times 10^{-10}$ $\mathrm{m}^{2} \mathrm{~s}^{-1}$ for the drying air temperatures of $20,30,40$, and $50{ }^{\circ} \mathrm{C}$, respectively (Table 3). Martins et al. (2015) found similar results for Serjania marginata leaves, with a $\mathrm{D}_{\text {ef }}$ increase from 0.6630 to $12.0712 \times 10^{-11} \mathrm{~m}^{2} \mathrm{~s}^{-1}$. According to Goneli et al. (2014a), these increases are dependent on temperature, concentration, vibration of water molecules, and volume of the product. Increase in temperature increases vibration of water molecules in the interior of the product, thus increasing its coefficient of effective diffusion (Goneli et al., 2008).

The $\mathrm{D}_{\text {ef }}$ of the bitter melon leaf drying was in the range of $10^{-11}$ to $10^{-9} \mathrm{~m}^{2} \mathrm{~s}^{-1}$, which is consistent with Zogzas et al. (1996), who found $\mathrm{D}_{\text {ef }}$ within this range for agricultural products.
The slope of the Arrhenius curve (Figure 2), generated from the values of $\ln \left(D_{\text {ef }}\right)$ as a function of the inverse absolute air temperature $(1 / \mathrm{Ta})$ during the bitter melon leaf drying, provides the $\mathrm{Ea} / \mathrm{R}$ ratio, whereas its intersection with the ordinate axis indicates the value of $\mathrm{D}_{0}$.

The correlation between the coefficient of effective diffusion and drying air temperature has been described satisfactorily by the Arrhenius equation (Martins et al., 2015). According to Gasparin et al. (2017), the linear fit indicates the uniformity of variation of the coefficient of diffusion as a function of temperature.

The activation energy (Ea) obtained by the Arrhenius model was $33.163 \mathrm{~kJ} \mathrm{~mol}^{-1}$. Silva et al. (2015) found similar result for Genipa americana leaves, with Ea of $33.87 \mathrm{~kJ} \mathrm{~mol}^{-1}$, and Martins et al. (2018) found lower results for blackberry leaves, with Ea of $66.08 \mathrm{~kJ} \mathrm{~mol}^{-1}$. The lower Ea found for the bitter melon leaves denotes the need for less energy to trigger the liquid diffusion process than that for blackberry leaves. Different activation energy values found for different agricultural products can be attributed to the physical and biological characteristics of the products (Martins et al., 2015).

According to Corrêa et al. (2007), Ea can be explained as the water molecule difficulty to overcome the energy barrier during their migration in the interior of leaves, since the lower the activation energy the higher the water diffusivity in the interior of the leaf during the drying process. The Ea found for the bitter melon leaf drying was within the range (12.7 to $110 \mathrm{~kJ} \mathrm{~mol}^{-1}$ ) for agricultural products proposed by Zogzas et al. (1996).

Regarding the thermodynamic properties, the enthalpy $(\Delta \mathrm{h})$ decreased from 30.726 to $30.477 \mathrm{~kJ} \mathrm{~mol}^{-1}$ as the temperature was increased (Table 4 ). This indicates the need for a lower quantity of energy for drying at high temperatures (Martins et al., 2015).

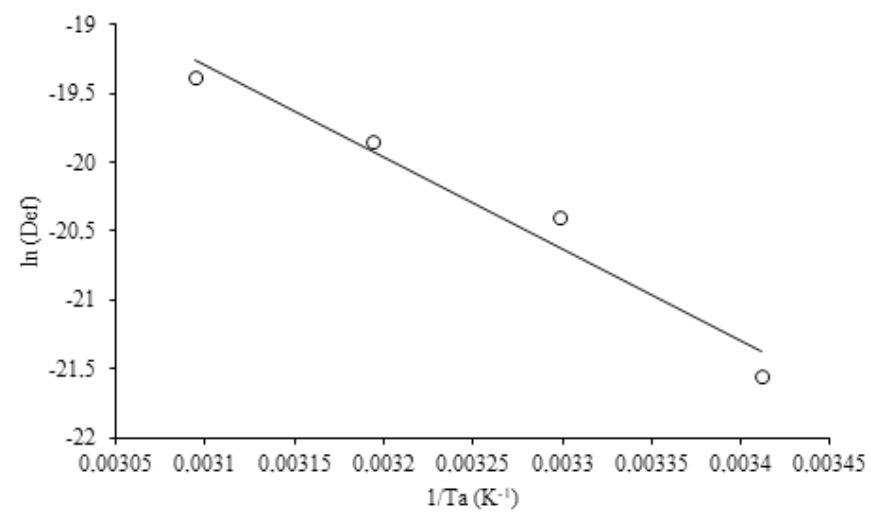

Figure 2. Arrhenius expression for the coefficient of effective diffusion $\left(\mathrm{D}_{\text {ef }}\right)$ as a function of the inverse absolute air temperature during the bitter melon leaf drying

Table 3. Parameters of the Midilli model $(a, b, k, n)$ and coefficient of effective diffusion $\left(D_{\text {ef }}\right)$ for different bitter melon leaf drying conditions

\begin{tabular}{ccccccccc}
\hline Temperature $\left({ }^{(} \mathbf{C}\right)$ & $\mathbf{a}$ & $\mathbf{k}$ & $\mathbf{n}$ & $\mathbf{b}$ & $\mathbf{D}_{\text {ef }}\left(\mathbf{m}^{2} \mathbf{s}^{-1}\right)$ & $\mathbf{R}^{\mathbf{2}}(\mathbf{\%})$ & $\mathbf{P}$ \\
\hline 20 & 0.997883 & 0.084531 & 0.893524 & -0.00130 & $4.3810^{-10}$ & 98.92 & 8.91 \\
30 & 0.991493 & 0.18 & 1.06 & -0.00134 & $13.910^{-10}$ & 97.54 & 9.04 \\
40 & 0.977481 & 0.33088 & 0.983439 & -0.00419 & $24.110^{-10}$ & 99.02 & 8.55 \\
50 & 1.002541 & 0.686053 & 0.908001 & $-1.010^{-12}$ & $38.110^{-10}$ & 98.33 & 7.62 \\
\hline
\end{tabular}

$\mathrm{R}^{2}$ - Coefficient of determination; $\mathrm{P}$ - Relative mean error 
Table 4. Enthalpy $(\Delta \mathrm{h})$, entropy $(\Delta s)$, and Gibbs free energy $(\Delta \mathrm{G})$ of the bitter melon leaf drying process

\begin{tabular}{cccc}
\hline $\begin{array}{c}\text { Temperature } \\
\left({ }^{\circ} \mathbf{C}\right)\end{array}$ & $\begin{array}{c}\Delta \mathbf{h} \\
\left(\mathbf{k J ~ m o l} \mathbf{~ m}^{-1}\right)\end{array}$ & $\begin{array}{c}\Delta \mathbf{S} \\
\left(\mathbf{k J ~ m o l}^{-1} \mathbf{K}^{-1}\right)\end{array}$ & $\begin{array}{c}\Delta \mathbf{G} \\
\left(\mathbf{k J ~ m o l}^{-1}\right)\end{array}$ \\
\hline 20 & 30.726 & -0.2276 & 97.3172 \\
30 & 30.643 & -0.2274 & 99.5901 \\
40 & 30.559 & -0.2277 & 101.8658 \\
50 & 30.477 & -0.2279 & 104.1442 \\
\hline
\end{tabular}

The entropy $(\Delta s)$ decreased from -0.2276 to $-0.2279 \mathrm{~kJ} \mathrm{~mol}^{-1} \mathrm{~K}^{-1}$, similarly to the enthalpy (Table 4). According to Corrêa et al. (2010), this result is expected, because decreases in temperature cause lower excitation of water molecules, increasing the order of the water-leaf system. The negative entropy is attributed to chemical adsorption or structural changes in the adsorbent (Moreira et al., 2008).

The Gibbs free energy $(\Delta G)$ increased from 97.3172 to $104.1442 \mathrm{~kJ} \mathrm{~mol}^{-1}$ as the temperature was increased. This characterizes an endothermic reaction, i.e., an external energy source is needed to increase the energy level and transform the reagents from the liquid to the vapor state (Ong et al., 2013).

\section{Conclusions}

1. Midilli and Page are the models that better represent the bitter melon (Momordica charantia L.) leaf drying.

2. Increases in temperature increase removal of water from bitter melon leaves during their drying.

3. The coefficient of effective diffusion and the Gibbs free energy increased as the drying temperature was increased, decreasing the enthalpy and entropy.

\section{ACKNOWLedgments}

This research was supported by the Federal Institute Goiano (Ceres campus), Foundation of Research Support of the State of Goiás (FAPEG), and Brazilian National Council for Scientific and Technological Development (CNPq).

\section{Literature Cited}

ASABE - American Society of Agricultural and Biological Engineers. Moisture measurement - Forages: Standard S358.2 DEC1988, R2008. In: American Society of Agricultural and Biological Engineers (Ed.). Standards, Engineering Practices, and Data. St. Joseph: ASABE, 2010, p.684-685.

Assis, J. P.; Sousa, R. P.; Linhares, P. C. F.; Pereira, M. F. S.; Moreira, J. C. Avaliação biométrica de caracteres do melão de São Caetano (Momordica charantia L.). Revista Brasileira de Plantas Medicinais, v.17, p.505-514, 2015. https://doi.org/10.1590/1983084X/13_062

Babalis, S. J.; Belessiotis, V. G. Influence of the drying conditions on the drying constants and moisture diffusivity during the thin-layer drying of figs. Journal of Food Agricultural Engineering, v.66, p.449-458, 2004. https://doi.org/10.1016/j.jfoodeng.2004.02.005

Brooker, D. B.; Bakker-Arkema, F. W.; Hall, C. W. Drying and storage of grains and oilseeds. Westport: The AVI Publishing Company, 1992. 450p.
Corrêa, P. C.; Oliveira, G. H. H.; Botelho, F. M.; Goneli, A. L. D.; Carvalho, F. M. Modelagem matemática e determinação das propriedades termodinâmicas do café (Coffea arabica L.) durante o processo de secagem. Revista Ceres, v.57, p.595-601, 2010. https://doi.org/10.1590/S0034-737X2010000500005

Corrêa, P. C.; Resende, O.; Martinazzo, A. P.; Goneli A. L. D.; Botelho, F. M. Modelagem matemática para a descrição do processo de secagem do feijão (Phaseolus vulgaris L.) em camadas delgadas. Engenharia Agrícola, v.27, p.501-510, 2007. https://doi. org/10.1590/S0100-69162007000300020

Corrêa Filho, L. C.; Martinazzo, A. P.; Teodoro, C. E. S.; Andrade, E. T. Post-harvest of parsley leaves (Petroselinum crispum): Mathematical modelling of drying and sorption processes. Revista Brasileira de Engenharia Agrícola e Ambiental, v.22, p.131-136, 2018. https://doi.org/10.1590/1807-1929/agriambi. v22n2p131-136

Draper, N. R.; Smith, H. Applied regression analysis. New York: John Wiley \& Sons, 1998. 712p. https://doi. org/10.1002/9781118625590

Gasparin, P. P.; Christ, D.; Coelho, S. R. M. Secagem de folhas Mentha piperita em leito fixo utilizando diferentes temperaturas e velocidades de ar. Revista Ciência Agronômica, v.48, p.242250, 2017.

Goneli, A. L. D.; Corrêa, P. C.; Resende, O.; Reis Neto, S. A. Propriedades físicas dos frutos de mamona durante a secagem. Revista Brasileira de Armazenamento, v.33, p.148-155, 2008. https://doi.org/10.4025/actasciagron.v33i1.4629

Goneli, A. L. D.; Nasu, A. K.; Gancedo, R.; Araújo, W. D.; Sarath, K. L. L. Cinética de secagem de folhas de erva baleeira (Cordia verbenacea DC.). Revista Brasileira de Plantas Medicinais, v.16, p.434-443, 2014b. https://doi.org/10.1590/1983-084X/13_041

Goneli, A. L. D.; Vieira, M. do C.; Vilhasanti, H. da C. B.; Gonçalves, A. A. Modelagem matemática e difusividade efetiva de folhas de aroeira durante a secagem. Pesquisa Agropecuária Tropical, v.44, p.56-64, 2014a. https://doi.org/10.1590/S198340632014000100005

Jideani, V. A.; Mpotokwana, A. S. M. Modeling of water absorption of Botswana bambara varieties using Peleg's equation. Journal of Food Engineering, v.92, p.182-188, 2009. https://doi.org/10.1016/j. jfoodeng.2008.10.040

Joly, A. B. Botânica: Introdução à taxonomia vegetal. São Paulo: Comp. Ed. Nacional, 1998. 777p.

Karizaki, V. M. Kinetic modeling and determination of mass transfer parameters during cooking of rice. Innovative Food Science and Emerging Technologies, v.38, p.131-138, 2016. https://doi. org/10.1016/j.ifset.2016.09.017

Martins, E. A. S.; Goneli, A. L. D.; Gonçalves, A. A.; Hartmann Filho, C. P.; Siqueira, V. C.; Oba, G. C. Drying kinetics of blackberry leaves. Revista Brasileira de Engenharia Agrícola e Ambiental, v.22, p.570-576, 2018. https://doi.org/10.1590/1807-1929/ agriambi.v22n8p570-576

Martins, E. A. S.; Lage, E. Z.; Goneli, A. L. D.; Hartmann Filho, C. P. H.; Lopes, J. G. Cinética de secagem de folhas de timbó (Serjania marginata Casar). Revista Brasileira de Engenharia Agrícola e Ambiental, v.19, p.238-244, 2015. https://doi.org/10.1590/18071929/agriambi.v19n3p238-244 
Mohapatra, D.; Rao, P. S. A thin layer drying model of parboiled wheat. Journal of Food Engineering, v.66, p.513-518, 2005. https://doi. org/10.1016/j.jfoodeng.2004.04.023

Moreira, R.; Chenlo, F.; Torres, M. D.; Vallejo, N. Thermodynamic analysis of experimental sorption isotherms of loquat and quince fruits. Journal of Food Engineering, v.88, p.514-521, 2008. https:// doi.org/10.1016/j.jfoodeng.2008.03.011

Ong, L. K.; Kurniawan, A.; Suwandi, A. C.; Lin, C. X.; Zhao, X. S. Ismadji, $\mathrm{S}$. Transesterification of leather tanning waste to biodiesel at supercritical condition: Kinetics and thermodynamics studies. The Journal of Supercritical Fluids, v.75, p.11-20, 2013. https:// doi.org/10.1016/j.supflu.2012.12.018

Rodovalho, R. S.; Silva, H. W. da; Silva, I. L.; Rossetto, C. A. V. Cinética de secagem dos grãos de pimenta bode. Global Science and Technology, v.8, p.128-142, 2015. https://doi.org/10.14688/19843801/gst.v8n2p128-142
Silva, L. A.; Resende, O. Virgolino, Z. Z.; Bessa, J. F. V.; Morais, W. A.; Vidal, V.M. Cinética de secagem e difusividade efetiva em folhas de jenipapo (Genipa americana L.). Revista Brasileira de Plantas Medicinais, v.17, p.953-963, 2015. https://doi.org/10.1590/1983-084X/14_106

Sousa, F. C.; Martins, J. J. A.; Rocha, A. P. T.; Gomes, J. P.; Pessoa, T.; Martins, J. N. Predição de modelos sobre a cinética de secagem de folhas de Ziziphus joazeiro Mart. Revista Brasileira de Plantas Medicinais, v.17, p.195-200, 2015. https://doi.org/10.1590/1983-084X/12_071

Viganó, J.; Azuara, E.; Telis, V. R. N.; Beristain, C. I.; Jiménez, M.; Telis-Romero, J. Role of enthalpy and entropy in moisture sorption behavior of pineapple pulp powder produced by different drying methods. Thermochimica Acta, v.528, p.63-71, 2012. https://doi. org/10.1016/j.tca.2011.11.011

Zogzas, N. P.; Maroulis, Z. B.; Marinos-Kouris, D. Moisture diffusivity data compilation in foodstuffs. Drying Technology, v.14, p.22252253, 1996. https://doi.org/10.1080/07373939608917205 